\title{
MODEL LATIHAN TRX (TOTAL BODY RESISTANCE EXERCISE) TERHADAP KEBUGARAN JASMANI
}

\author{
I Kadek Suardika ${ }^{1}$, Ketut Agus Artha ${ }^{2}$ \\ ${ }^{1,2}$ Program Studi Pendidikan Olahraga dan Kesehatan STKIP Agama Hindu \\ Singaraja, Indonesia \\ e-mail : deksuguard@gmail.com, agusartha001@gmail.com
}

\begin{abstract}
Abstrak
Penelitian ini didasarkan pada permasalahan aktivitas fisik remaja kini semakin dipermudah dengan IPTEK yang serba modern sehingga tidak heran jika ketidakaktifan fisik dapat menjadi permasalahan kesehatan yang utama. Tujuan penelitian ini untuk mengetahui efektivitas variasi model latihan TRX untuk meningkatkan kebugaran jasmani pada siswa SMA Laboratorium Undiksha Singaraja. Jenis penelitian ini adalah penelitian eksperimen. Subjek penelitian adalah siswa SMA Laboratorium Undiksha Singaraja yang berjumlah 30 orang. Hasil penelitian pelatihan TRX ternyata nilai beda rata-rata antara pretest dan posttest adalah sebesar 8,80. Sedangkan persentase peningkatan rata-rata sebesar 29,33\%. Hasil tersebut dapat dikatakan bahwa pelatihan pelatihan TRX ternyata dapat meningkatkan kebugaran jasmani sebesar 29,33\%. pelatihan $T R X$ mempunyai pengaruh yang lebih baik terhadap hasil kebugaran jasmani dari kelompok kontrol pada siswa SMA Laboratorium Undiksha Singaraja. Simpulan dalam penelitian ini adalah pemberian pelatihan $T R X$ berpengaruh signifikan terhadap peningkatan kebugaran jasmani siswa SMA Laboratorium Undiksha Singaraja.
\end{abstract}

Kata-kata kunci : model latihan, TRX, kebugaran jasmani.

\begin{abstract}
The background of this research is based on the problem of physical activity of adolescents now increasingly facilitated by modern-day science and technology so it is not surprising that physical inactivity can be a major health problem. The aim is to find out whether the variation of TRX exercise model is effective to improve physical fitness in Undiksha Singaraja Laboratory High School students. This type of research is experimental research. The research subjects were 30 Undiksha Singaraja Laboratory High School students. The results of the TRX training study showed that the average difference between pretest and posttest was 8.80. While the average percentage increase was $29.33 \%$. These results can be said that TRX Training training turned out to improve physical fitness by 29.33\%. TRX training has a better influence on physical fitness results from the control group at Undiksha Singaraja Laboratory High School students. The conclusions in this study are that TRX training has a significant effect on improving the physical fitness of Undiksha Singaraja Laboratory High School students.
\end{abstract}

Keywords: excercise, TRX, physical fitness. 


\section{PENDAHULUAN}

Kesegaran Jasmani adalah kemampuan untuk melakukan kerja atau aktivitas, mempertinggi daya kerja dengan tanpa mengalami kelelahan yang berarti atau berlebihan. Aktivitas fisik adalah setiap gerakan tubuh yang dihasilkan oleh otot rangka yang memerlukan pengeluaran energi. Aktivitas fisik yang tidak ada (kurangnya aktivitas fisik) merupakan faktor risiko independen untuk penyakit kronis, dan secara keseluruhan diperkirakan menyebabkan kematian secara global (WHO, 2010). Aktivitas fisik remaja kini semakin dipermudah dengan IPTEK yang serba modern seperti saat ini, transportasi dengan menggunakan kendaraan, pemakaian alat-alat yang menghemat tenaga kerja, dan aktivitas kurang gerak demi kenyamanan hidup seperti menonton televisi dan penggunaan gadget yang berlebihan, maka tidak heran jika ketidakaktifan fisik dapat menjadi permasalahan kesehatan yang utama. Aktivitas di era modern ini dengan perkembangan IPTEK yang semakin maju, maka aktivitas yang seharusnya membutuhkan aktivitas fisik yang besar kini dapat dilakukan dengan mudah dan sedikit gerak. Berbagai sarana menyebabkan gerak dan aktivitas menjadi semakin terbatas dan hidup semakin santai karena segalanya sudah tersedia (Hudha, 2006). Namun seiring perkembangan IPTEK yang serba modern dan menunjang hidup manusia lebih praktis, IPTEK di dunia olahraga juga tidak ketinggalan untuk menyuguhkan bentuk metode latihan yang pratis untuk melengkapi kebiasaan-kebiasaan manusia di jaman sekarang yang lebih meminati hal yang lebih praktis tapi tidak mengurangi makna kebugaran, banyak bentuk latihan fisik yang bisa diterapkan untuk meningkatkan kebugaran jasmani, salah satunya adalah metode latihan terbaru yaitu TRX (Total Body Resistance Exercise).

TRX merupakan salah satu model latihan fisik yang mempergunakan alat berupa tali sebagai alat bantu latihan. Latihan ini juga merupakan salah satu model latihan tahanan yang menggunakan beban dalam (berat tubuh sendiri). Model latihan TRX termasuk salah satu latihan fisik yang dapat menjaga dan meningkatkan kekuatan, daya tahan otot, stability, dan meningkatkan koordinasi otot syaraf. Model latihan TRX merupakan model latihan yang special, karena selain dapat melatih kekuatan dan daya tahan otot, juga sekaligus melatih otot inti (core). Pola gerakan yang dinamis membuat otot inti harus menjaga keadaan tubuh agar tetap lurus ataupun menyesuaikan dengan gerakan yang diinginkan. Berdasarkan observasi yang peneliti lakukan di Jurusan Pendidikan Pelatihan Olahraga diperdalam dengan wawancara terhadap dosen pengampu mata kuliah TP. Pembentukan Kondisi Fisik dan TP. Pembinaan Prestasi. Hasil awal dari hasil observasi dan wawancara menunjukkan bahwa (1) dosen pengampu mata kuliah TP. Pembentukan Kondisi Fisik dan TP. Pembinaan Prestasi belum pernah menggunakan model latihan TRX dan tidak memiliki pengetahuan tentang model latihan TRX, (2) dosen pengampu mata kuliah TP. Pembentukan Kondisi Fisik dan TP. Pembinaan Prestasi sangat tertarik dengan pengembangan model latihan TRX yang baru untuk meningkatkan kebugaran jasmani, (3) memiliki pemahaman terhadap model pelatihan TRX untuk meningkatkan kebugaran jasmaninya.

Menurut hasil penelitian yang dilakukan oleh Y1lmaz (2014), 
menunjukkan bahwa latihan ketahanan tubuh selama 12 minggu memiliki efek optimal pada komposisi tubuh dan status tulang, namun tidak berpengaruh pada berat badan dan indeks massa tubuh pada subjek wanita muda. Jadi secara tidak langsung menjaga ketahanan tubuh dapat menjaga kondisi fisik tubuh.

Berdasarkan hasil wawancara di lapangan dan kondisi yang ada, maka dirasa perlu untuk mengembangkan suatu model latihan fisik berupa latihan TRX untuk peningkatan kebugaran jasmani.

Model latihan TRX bisa didefinisikan sebagai metode latihan tahanan yang menggunakan berat badan sendiri sebagai beban dengan bantuan tali. Latihan ini bisa dibilang latihan yang unik, yang secara umum menggunakan tangan atau kaki pada titik jangkar tunggal, sementara badan tidak kontak dengan lantai.Ini memberikan ketidakstabilan, sehingga memungkinkan pengguna TRX untuk melatih fleksibilitas, integritas gabungan, pencegahan cedera, dan keseimbangan.Hal tersebut sangat sesuai dengan kebutuhan latihan di jaman sekarang ini yang mana orang suka dengan hal-hal yang praktis.
Dengan menggunakan beban sendiri maka pembebanan yang dialami oleh otot pengguna tidaklah terlalu berat, akan tetapi dapat memberikan tahanan yang sesuai dengan kebutuhan latihan yang dibutuhkan oleh pengguna. Latihan dimulai dari level yang ringan kemudian ke level yang lebih berat hal tersebut untuk memberikan peningkatan pembebanan sehingga daya tahan dan kekuatan meningkat sesuai dengan yang diharapkan. Dengan bantuan alat TRX dapat melakukan latihan fisik yang beragam, sehingga tujuan latihan dapat tercapai dengan baik.

Kelebihan Latihan TRX

a) Setiap model latihan yang dilakukan melatih otot utama dan sekaligus melatih core (otot inti).

b) Praktis, latihan dapat dilakukan di banyak tempat, hal tersebut sangat menguntungkan untuk menghindari kejenuhan latihan.

c) Mudah digunakan dan ada level nya, bisa pilih tingkat kesulitan di tiap gerakannya.

d) Biasanya kalo latihan weight training otot terkesan kaku, tapi dengan latihan TRX otot Lebih fleksibel.

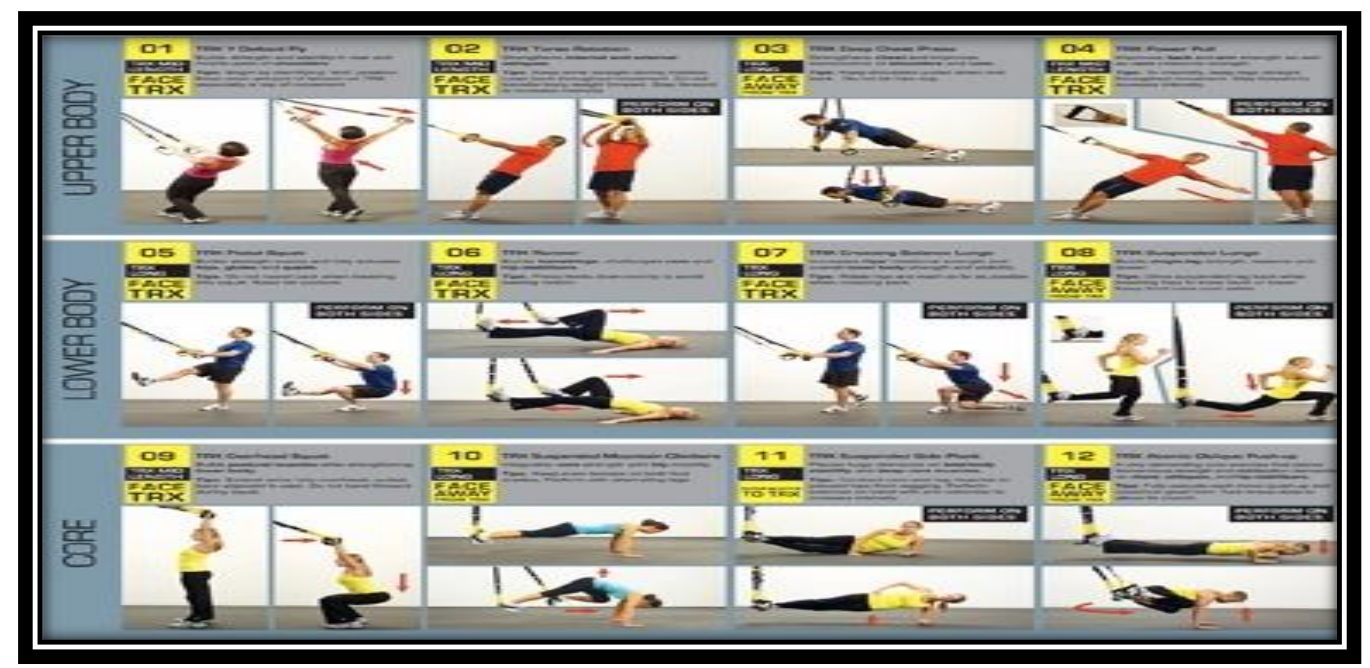

Gambar 2.1 Latihan TRX 


\section{METODE PENELITIAN}

Metode yang digunakan dalam penelitian ini adalah metode eksperimental. Metode elsperimental merupakan metode penelitian tang memungkinkan peneliti yang memungkinkan peneliti memanipulasi variabel dan meneliti akibat-akibatnya. Pada metode ini variabel-variabel dikontrol sedemikian rupa, sehingga variabel luar yang mungkin mempengaruhi dapat dihilangkan. Metode eksperimental bertujuan untuk mencari hubungan sebab akibat dengan manipulasi satu atau lebih variabel, pada satu atau lebih kelompok eksperimental dan membandingkan hasilnya dengan kelompok control yang tidak mengalami manipulasi. Lokasi yang digunakan dalam penelitian ini adalah GOR Bhuwana Patra dan Aula
Jurusan Pendidikan Olahraga dan Kesehatan STKIP Agama Hindu Singaraja Singaraja. Yang menjadi subjek penelitian adalah siswa siswi SMA Laboratorium Undiksha Singaraja yang berjumlah 30 orang.

\section{HASIL DAN PEMBAHASAN Hasil}

Hasil tes tersebut akan dicatat dan dihitung berdasarkan kelompok dan jenis pelatihan yang diterapkan. Di sini akan dianalisa hasil dari ke 2 kelompok tersebut (experiment dan kontrol). Berdasarkan hasil analisis dengan menggunakan program SPSS for Windows 17.0, selanjutnya deskripsi data dari hasil penelitian dapat dijabarkan lebih lanjut dalam bentuk tabel sebagai berikut.

Tabel 1. Deskripsi Hasil Pretest dan Posttest Pelatihan TRX Kelompok Pelatihan dan Kelompok Kontrol.

\begin{tabular}{|c|c|c|c|c|}
\hline \multirow{2}{*}{ Deskripsi } & \multicolumn{2}{|c|}{$\begin{array}{l}\text { Kelompok I } \\
\text { Pelatihan } \\
\text { TRX }\end{array}$} & \multicolumn{2}{|c|}{$\begin{array}{c}\text { Kelompok III } \\
\text { Kontrol }\end{array}$} \\
\hline & Pretest & Posttest & Pretest & Posttest \\
\hline Rata-rata/Mean & 30.00 & 38.80 & 28.70 & 31.60 \\
\hline Standar Deviasi & 4.37 & 3.91 & 3.65 & 3.47 \\
\hline Varians & 19.11 & 15.29 & 13.34 & 12.04 \\
\hline Nilai Tertinggi & 40.00 & 45.00 & 34.00 & 36.00 \\
\hline Nilai Terendah & 26.00 & 35.00 & 22.00 & 25.00 \\
\hline Persentase Peningkatan & \multicolumn{2}{|c|}{$29,33 \%$} & \multicolumn{2}{|c|}{$10,10 \%$} \\
\hline
\end{tabular}

Dari tabel 1 di atas, maka dapat diketahui bahwa:

1. Kelompok I (Pelatihan TRX).

a. Hasil tes sebelum diberikan pelatihan TRX (pretest) adalah rata-rata sebesar 30,00, sedangkan hasil tes tertinggi dan terendah adalah 40,00 dan
15,00. Nilai varian dan standar deviasi pretest sebesar 19.11 dan 4.37.

b. Nilai beda rata-rata antara pretest dan posttest adalah sebesar 8,80. Sedangkan persentase peningkatan rata-rata sebesar 29,33\%. Hasil tersebut 
dapat dikatakan bahwa pelatihan Pelatihan TRX ternyata dapat meningkatkan kebugaran jasmani sebesar 29,33\%.

2. Kelompok II (Kontrol).

a. Hasil test TKJI kelompok kontrol (pretest) adalah rata-rata sebesar 28.70, sedangkan hasil tes TKJI tertinggi dan terendah adalah 34,00 dan 22,00. Nilai varian dan standar deviasi pretest sebesar 13,34 dan 3,65.

b. Nilai beda rata-rata antara pretest dan posttest adalah sebesar 2,9. Sedangkan persentase peningkatan rata-rata sebesar $10,10 \%$. Hasil tersebut dapat dikatakan bahwa pada kelompok kontrol terjadi peningkatan sebesar 10,10\%.

Dari penjelasan di atas, dapat diketahui bahwa ada perbedaan hasil tes dari kedua kelompok perlakuan tersebut (experiment dan kontrol). Ini terlihat dari nilai rata-rata posttest lebih tinggi daripada nilai rata-rata pretest dari kelompok experimen pelatihan tersebut. Ini berarti bahwa pemberian pelatihan TRX ternyata memberikan pengaruh lebih baik terhadap peningkatan kondisi fisik siswa SMA Laboratorium Undiksha Singaraja.

Berdasarkan hasil Uji Normalitas dengan alat bantu komputer yang menggunakan Program SPSS. 17.0. diperoleh hasil :

Tabel. 2. Hasil Uji Normalitas Data Kelompok I dan II

\begin{tabular}{ccccc}
\hline $\begin{array}{c}\text { One-Sample } \\
\text { Kolmogorov-Smirnov }\end{array}$ & \multicolumn{2}{c}{$\begin{array}{c}\text { Kelompok I } \\
\text { TRX }\end{array}$} & \multicolumn{2}{c}{$\begin{array}{c}\text { Kelompok II } \\
\text { Kontrol }\end{array}$} \\
Test & Pretest & Posttest & Pretest & Posttest \\
\hline N & 10 & 10 & 10 & 10 \\
Kolmogorov-Smirnov Z & 0,632 & 0,832 & 0,509 & 0,461 \\
Asymp. Sig. (2-tailed) & 0,819 & 0,493 & 0,958 & 0,984
\end{tabular}

\section{Test Distribution is Normal}

Hasil perhitungan tabel 2 di atas dapat diinterprestasikan sebagai berikut:

1) Besarnya nilai Asymp. Sig. (2-tailed) data pretest kelompok I sebesar 0,819 lebih besar dari 0,05. Sesuai kriteria pengujian dapat dikatakan bahwa data pretest tes TKJI kelompok experimen berdistribusi normal.

2) Besarnya nilai Asymp. Sig. (2-tailed) data posttest kelompok I sebesar 0,493 lebih besar dari 0,05 . Sesuai kriteria pengujian dapat dikatakan bahwa data posttest tes TKJI kelompok experimen berdistribusi normal.

3) Besarnya nilai Asymp. Sig. (2-tailed) data pretest kelompok II sebesar
0,958 lebih besar dari 0,05. Sesuai kriteria pengujian dapat dikatakan bahwa data pretest tes TKJI kelompok experimen berdistribusi normal.

4) Besarnya nilai Asymp. Sig. (2-tailed) data posttest kelompok II sebesar 0,984 lebih besar dari 0,05. Sesuai kriteria pengujian dapat dikatakan bahwa data posttest tes TKJI kelompok experimen berdistribusi normal.

Berdasarkan hasil perhitungan di atas diketahui besarnya nilai Asymp. Sig. (2-tailed) dari semua kelompok (I dan II) baik pretest maupun posttest lebih besar dari 5\% $(0,05)$, hal ini dapat dikatakan bahwa sebaran data dari 
kelompok I dan II baik pretest maupun posttest adalah Program SPSS 17.0. diperoleh hasil sebagai berikut :

Tabel 3 Hasil Uji Homogenitas

Test of Homogeneity of Variances

\begin{tabular}{cccc}
$\begin{array}{l}\text { Dependent Variable : } \\
\text { pelatihan TRX } \\
\text { Kelompok }\end{array}$ & $\begin{array}{c}\text { Levene } \\
\text { Statistic }\end{array}$ & TKJI & Keterangan \\
\hline $\begin{array}{l}\text { Pelatihan TRX } \\
\text { Kontrol }\end{array}$ & 0.835 & 0.445 & Homogen \\
\hline
\end{tabular}

Dari tabel 3 hasil perhitungan uji homogenitas di atas, dapat diketahui bahwa: nilai levene statistic sebesar 0.835 dan nilai Sig. $(P=0.445)$, karena nilai Sig. $(P=$ $0.445>0,05)$ sesuai dengan kriteria maka dapat dikatakan sebaran data dari kelompok pelatihan experiment dan kontrol mempunyai varian yang sama (homogen). Oleh karena itu untuk keperluan analisis uji beda rata-rata antar kelompok diambil dari nilai Equal Variances Assumed (untuk data yang homogen).

\begin{abstract}
Uji Beda Antar Kelompok (Anova Satu Jalur)

Pengujian beda rerata antar kelompok secara serempak dilakukan dengan menggunakan Analisis varian (Anova). Menurut Maksum (2012: 182) One Way Anova adalah teknik statistik parametrik yang digunakan untuk menguji perbedaan antara dua atau lebih kelompok data. Adapun langkah-langkah dalam perumusan uji hipotesis sebagai berikut:
\end{abstract}

Tabel 4 Hasil Perhitungan Anova (pelatihan TRX)

\begin{tabular}{cccccc}
\hline \multicolumn{5}{c}{ ANOVA } & \\
& Sum of Squares & Df & Mean Square & $F$ & Sig. \\
\hline Between Groups & 258.067 & 2 & 129.033 & 21.127 & .000 \\
Within Groups & 164.900 & 27 & 6.107 & & \\
Total & 422.967 & 29 & & & \\
\hline
\end{tabular}

Hasil perhitungan anova di atas dapat diinterprestasikan terima $\mathrm{Ha}$ karena nilai $F_{\text {hitung }} 21,127>$ nilai $F_{\text {tabel }}$ 3,35. Dengan kata lain bahwa terdapat perbedaan yang signifikan antara hasil pelatihan kelompok TRX dan kontrol terhadap Pelatihan TRX pada siswa SMA Laboratorium Undiksha Singaraja. Hal ini dapat dikatakan bahwa dua kelompok pelatihan tersebut mempunyai pengaruh yang berbeda terhadap peningkatan kondisi fisik pada siswa SMA Laboratorium Undiksha Singaraja.

Untuk mengetahui kelompok apa saja yang berbeda dari kedua kelompok tersebut, maka dilakukan perhitungan post hoc, adapun hasil dari perhitungan post hoc test (output SPSS 17.0 for Windows) didapatkan sebagai berikut : 
Tabel 5. Hasil Uji Beda Rata-Rata Antar Kelompok (Post Hoc Test)

\begin{tabular}{|c|c|c|c|c|c|c|}
\hline \multirow{2}{*}{$\begin{array}{c}\text { (I) } \\
\text { kelompok }\end{array}$} & \multirow{2}{*}{$\begin{array}{c}(\mathbf{J}) \\
\text { kelompok }\end{array}$} & \multirow{2}{*}{$\begin{array}{c}\text { Mean } \\
\text { Difference (I- } \\
\mathbf{J})\end{array}$} & \multirow{2}{*}{$\begin{array}{l}\text { Std. } \\
\text { Error }\end{array}$} & \multirow{2}{*}{ Sig. } & \multicolumn{2}{|c|}{$\begin{array}{l}\text { 95\% Confidence } \\
\text { Interval }\end{array}$} \\
\hline & & & & & Lower Bound & $\begin{array}{l}\text { Upper } \\
\text { Bound }\end{array}$ \\
\hline \multicolumn{7}{|l|}{ Pelatihan } \\
\hline TRX & Control & $5.90000^{*}$ & 1.10521 & .000 & 3.6323 & 8.1677 \\
\hline kontrol & TRX & $-5.90000^{*}$ & 1.10521 & .000 & -8.1677 & -3.6323 \\
\hline
\end{tabular}

Dari hasil perhitungan LSD pada tabel 5 di atas dapat diinterpretasikan sebagai berikut:

1. Hasil pelatihan $T R X$ dan kelompok kontrol berbeda secara signifikan, dengan nilai perbedaan sebesar 5,90.

2. Hasil analisis LSD di atas menunjukan bahwa kedua kelompok tersebut ternyata berbeda secara signifikan, Hal ini berarti bahwa pelatihan $T R X$ mempunyai pengaruh yang lebih baik (efektif) terhadap peningkatan kondisi fisik dari hasil tes TKJI siswa SMA Laboratorium Undiksha Singaraja (sesuai hasil analisis deskripsi) telah teruji kebenaranya.

\section{Pembahasan}

Dari hasil penelitian yang telah didapatkan, maka disusun suatu pembahasan menganai hasil-hasil dari analisis penelitian tersebut. Pembahasan di sini membahas penguraian hasil penelitian tentang pemberian latihan TRX terhadap kebugaran jasmani. Studi penelitian ini menggunakan 30 sampel penelitian yang terbagi kelompok pelatihan dan kelompok kontrol masingmasing 15 sampel. Hasil penelitian yang dilakukan dengan pemberian perlakuan TRX dan kolompok kontrol (konvensional). Menurut Bompa (1999: 209) mengatakan untuk menjalani latihan secara umum dengan banyak latihan (9-12) kali dilakukan dengan nyaman tanpa adanya tekanan pada atlet, merupakan hal yang diharapkan.

Pelatihan TRX memiliki variasi gerakan yang cukup banyak dan beraneka ragam, akan tetapi dalam penelitian ini peneliti hanya menggunakan 10 model latihan/variasi gerakan TRX. Alasan peneliti memilih latihan tersebut didasarkan karena latihan tersebut lebih mendominasi peningkatan kondisi fisik. Pengorganisasian dan perencanaan harus dilakukan oleh pelatih yang peranannya sangat luas, tidak hanya sebagai pendidik semata, melainkan tugasnya sangat kompleks, kenapa pelatih harus selalu mempertimbangkan banyak variabel seperti fisiologis, psikologis dan aspek sosial.

Latihan TRX adalah jenis latihan yang digunakan untuk meningkatkankondisi fisik. Sesuai dengan rumusan masalah dan tujuan penelitian tentang bagaimana pengaruh latihan TRX terhadap tingkat kebugaran jasmani siswa SMA Laboratorium Undiksah Singaraja dimana dihasilkan bahwa latihan TRX mempunyai pengaruh yang baik (efektif) terhadap hasil peningkatan kondisi fisik dengan tes TKJI. Untuk selanjutnya akan dibahas dan diuraikan secara lengkap tentang diskusi hasil-hasil yang sudah diperoleh sebagai berikut:

Penelitian yang dilakukan oleh Ed Lacy \& Barbara Marshall (2013) tentang peningkatan kebugaran fisik 
untuk anak-anak sekolah menemukan bahwa motivasi, individualisasi, dan umpan balik sangat penting elemen dalam kesuksesan program kebugaran, pada penelitian Chao Ou-Yang dkk (2014) menemukan bahwa latihan yang dapat meningkatkan kebugaran yang baik dapat digunakan untuk memperbaiki suatu proses kesiapan dan kesigapan, dan pada penelitian AnneMarie Elbe dkk (2016) menemukan bahwa pengembangan latihan dan kerjasama secara positif berdampak pada peningkatan kebugaran.

Pengaruh pelatihan TRX terhadap peningkatan kebugaran jasmani. Program perlakuan pelatihan TRX setelah diberi perlakuan selama dua belas minggu dengan frekuensi tiga kali per minggu menunjukan ada peningkatan pada kebugaran jasmani dilihat dari hasil perhitungan uji $\mathrm{t}$ sampel berpasangan (paired sample $t$ test) menyatakan bahwa nilai $t_{\text {hitung }}$ dan $t_{\text {tabel, }}$ maka dapat disimpulkan bahwa $\mathrm{Ho}$ ditolak dan $\mathrm{Ha}$ diterima karena nilai $t_{\text {hitung }} 16,500>$ nilai $t_{\text {tabel }} 1,833$, ini menyatakan terdapat perbedaan yang signifikan antara pelatihan TRX terhadap peningkatan kebugaran jasmani. Hal ini dapat dikatakan bahwa pemberian pelatihan $T R X$ berpengaruh terhadap peningkatan kebugaran jasmani siswa SMA Laboratorium Undiksha Singaraja. Sedangkan peningkatan kondisi fisik sebesar 29,33\%. Dengan demikian, hasil analisis di atas lebih menjawab pertanyaan penelitian dan hipotesis penelitian ini.

\section{SIMPULAN DAN SARAN}

Berdasarkan analisis data dan pembahasan di atas dapat disimpulkan:

1. Terdapat perbedaan yang signifikan antara hasil pelatihan kelompok TRX dan kontrol terhadap Pelatihan TRX pada siswa SMA Laboratorium
Undiksha Singaraja. Hal ini dapat dikatakan bahwa dua kelompok pelatihan tersebut mempunyai pengaruh yang berbeda terhadap peningkatan kondisi fisik pada siswa SMA Laboratorium Undiksha Singaraja.

2. Pelatihan $T R X$ mempunyai pengaruh yang lebih baik (efektif) terhadap peningkatan kondisi fisik dari hasil tes TKJI siswa SMA Laboratorium Undiksha Singaraja (sesuai hasil analisis deskripsi) telah teruji kebenaranya.

\section{DAFTAR PUSTAKA}

Anne-Marie Elbe dkk. 2016. The importance of cohesion and enjoyment for the fitness improvement.

European jurnal of sport science. https://doi.org/10.1080/1746139 $\underline{1.2016 .1260641}$

Chao Ou-Yang dkk. 2014. An Integrated mining approach to discover business process models with parallel structures: towards fitness improvement. International jurnal of production research. https://doi.org/10.1080/0020754 $\underline{3.2014 .974847}$

Giam dan Teh. 1993. Ilmu Kedokteran Olahraga. Jakarta Barat: Binarupa Aksara.

Gibney, Mikhael J. (et al). 2009. Gizi Kesehatan Masyarakat. Jakarta: EGC.

Hudha, L. 2006. "Hubungan antara pola makan dan aktivitas fisik dengan obesitas". Skripsi. Semarang: Universitas Negeri Semarang.

Kosasih, Engkos. 1993. Pendidikan Jasmani Olahraga dan 
Kesehatan Teori dan Praktek. Jakarta : Erlangga.

Lacy \& Barbara Marshall. 2013. Fitnessgram: An Answer to Physical Fitness Improvement for School Children. Jurnal Physical Education, Recreation and Dance. https://doi.org/10.1080/0730308 $\underline{4.1984 .10629623}$

Lutan, Rusli. 2002. Menuju Sehat Bugar. Jakarta : Dirjen Olahraga.

Olahraga. 2014. Pengertian Aktivitas Fisik. Diakses: 7 mei 2016. file:///F:/Pengertian Aktivitas Fisik psychologymania.htm.

Parista, S.V, Hanani, S.E, Setiawan, Ipang (2016). pengaruh permainan outbound mystique ball terhadap tingkat kebugaran jasmani siswa. journal of physical education, sport, health and recreations, 5 (3), 22526773

Pusat Kesegaran Jasmani Dan Rekreasi. 2000. Tes Kesegaran Jasmani Indonesia Untuk Remaja Umur 16-19 Tahun. Jakarta: Pusat Kesegaran Jasmani Dan Rekreasi.

Roji. 2007. Pendidikan Jasmani, Olahraga dan Kesehatan. Jakarta : Erlangga.

Rosdiani, Dini. 2013. Perencanaan Pembelajaran Dalam Pendidikan Jasmani Dan Kesehatan. Bandung: Alfabeta.

Sujianto, A. E. 2009. Aplikasi Statistik dengan SPSS 16.0. Jakarta: PT. Prestasi Pustakaraya.

TRX. 2014. TRX Exercise (Mengenal Latihan Unik; TRX). Diakses: 7
Mei 2016.

Johansyahlubis.blogspot.co.id.

Utari, Agustini. 2007. Hubungan Indeks Masa Tubuh dengan Tingkat Kesegaran Jasmani pada Anak Usia 12-14 Tahun. Tesis. Semarang: Jurusan Kedokteran Universitas Diponegoro.

Yilmaz, uçan (2014). effects of whole body resistance training on bone status and body composition in young females. journal of physical education and sport sciences, 8 (3), ,716-3774 